\title{
Multidimensional Poverty and Fertility in Congo
}

\author{
Samuel Ambapour1, Jean Christophe Okandza², Hylod Armel Moussana1 \\ ${ }^{1}$ Institut National de la Statistique, Brazzaville, Republic of Congo \\ ${ }^{2}$ Faculté des Sciences Economiques, Université Marien Ngouabi, Brazzaville, Republic of Congo \\ Email:ambapour_samuel@yahoo.fr, jcokandza@gmail.com,hylodmoussana@yahoo.fr
}

Received 11 February 2016; accepted 21 March 2016; published 24 March 2016

Copyright (C) 2016 by authors and Scientific Research Publishing Inc.

This work is licensed under the Creative Commons Attribution International License (CC BY).

http://creativecommons.org/licenses/by/4.0/

(c) (i) Open Access

\begin{abstract}
According to the well-known hypothesis stated in "The New Home Economics", theory that it associated with the name of Becker, poverty leads to a high fertility. Throughout this text, this hypothesis will be tested using data from the 2005 Demographic and Health Survey of Congo, knowing that poverty will be tackled in a non-monetary and multidimensional approach; and fertility in a parity view, that is to say the number of children a woman gave birth during the five years preceding the survey.
\end{abstract}

\section{Keywords}

Critical Assets, Capabilities, Fertility, Functionings, Socio-Economic Stratification, Parity

\section{Introduction}

In demo-economic literature, there are many debates relating to the different researches in the relationship between poverty and fertility led in several countries. It is obvious that, from poverty-fertility relationship arise different results depending on the indicator of poverty [1]-[3]. Indeed, there are varieties of indicators as much as it is for poverty (total household income, income per person, composite indicator, socio-economic class, etc.) as it is for fertility (total fertility rate, parity by age, progeny by age, total global fertility rate, etc.). In this paper, parity is used as fertility indicator: the number of children a woman gave birth during the five year preceding the survey; and poverty is tackled in a non-monetary and multidimensional approach, in other words, it is considered under three approaches [4] [5]: critical assets, socio-economic stratification of household standard of living, and Sen's capabilities ${ }^{1}$ [6] [7]. In the first view, called traditional, few elements relating to housing and comfort are used as regresses in the study of the poverty-fertility relationship. In the second view, considered as

${ }^{1}$ Poverty is reflected by a lack of elementary functional capacities to reach certain acceptable minimums. 
limited, we can perform a wealth indicator for each household based on physical assets in relation to housing and durable goods, which latter indicator allows to group household in different classes. Sen's approach of capabilities and functioning focuses on a micro-dimensional indicator of poverty. The different physical assets and durable goods are classified and marked according to the level of precariousness or non-precariousness. Within each group, a summation is then performed and a level of livelihood is chosen. The functioning that comes out is expressed in terms of gaps or deficits compared to the level of respective livelihoods.

The outline of the document is the following: in the next section, we specify the origin of data, as well as the indicators used in the study of poverty-fertility relationship. The third Section introduces the econometric procedures used. In the fourth Section, we provide the results of the econometric estimation. And finally, we discuss our results in Section five.

\section{Data and Indicators Used}

\subsection{Data}

The data used come from the first Demographic and Health Survey of Congo, conducted in 2005 by the National Center of Statistics and Economic Studies, in collaboration with ORC Macro [8]. Our study focuses on a sample of 3928 women aged between 15 to 49 years, about who we had enough information based on the selected indicators. However, it important to know that this survey did not contain data relating to monetary indicators of standard of living. Therefore, it is impossible to talk about poverty according to the monetary aspect for which many studies has been focused on to either determine a poverty line [9], or to calculate indices of poverty [10]. In these conditions, we give up consideration of the monetary aspect of poverty to the profit of other approaches where income (or expenses) do not allowed evaluation of all the dimensions of poverty [6]. In this context, the non-monetary approach based on the use of information relating to assets and household living conditions provides an interesting alternative. This is the context in which this document is written. Those information are about physical assets of households and include two elements: the characteristics of housing and the availability of durable goods. The elements relating to housing and comfort are the following: nature of the walls; nature of the roof; type of material comfort; mode of access to water; energy for cooking. Household assets regard a limited number of functional goods, in relation with transportation, habitation or communication.

The table below presents the outcomes of women fertility, according to the socio-economic characteristics (Table 1).

\subsection{Indicators Used}

\subsubsection{Poverty Indicators}

Three multidimensional and non-monetary approaches are used: critical assets, socio-economic stratification of the household standard of living and Sen's capabilities.

1) Critical Assets

Poor households are specified compare to the degree of insecurity, in terms of access to a number of assets, specifically: durable goods (radio, TV, stove, etc.) and the housing characteristics, especially sanitation (source of drinking water, type of toilet) and the housing (access to electricity, type of floor). Therefore for any household $i$, and for any asset $j$, we obtains a table $X$ whose data are 0 and 1 (Boolean value):

$x_{i j}=0$ if the household $i$ has no access to assets $j=1$ otherwise. In this case the criterion of poverty used is the following: $\sum\left\{x_{i j} \mid j \in J\right\}=0$, the household is poor; $\geq 1$ otherwise ( $J$ being the total set of indicators).

Thus, for a level of precariousness set to 0 , are considered as poor: households whose access to durable goods are not guaranteed; those who do not have access to drinking water; households with a dirt floor (soil/sand); households without modern toilets; and finally, those who do not have access to electricity.

2) Socio-economic stratification of the standard of living

The first step is to estimate an indicator of wealth for each household based on the weighted sum of various indicators of well-being [11]-[14]. Let's $X_{i}$ be the wealth indicator for the household $i, x_{i j}$ owned in basics needs $j$ and by $\alpha_{j}$ the weight of each basic need, the expression of $X_{i}$ is: $X_{i}=\alpha_{1} x_{i j}+\cdots+\alpha_{j} x_{i j}$.

Different technics of multivariate analysis are often used to construct this indicator [15]. According to Meulman'sworks [16], one use non-linear principal component analysis with optimal encoding [4] [5]. Some researchers prefer confirmatory analysis [14], because this method can be satisfied by a limited number of common 
Table 1. Socio-economic and community characteristics of fertility.

\begin{tabular}{|c|c|c|c|c|c|}
\hline Socio-economic Characteristics & $\begin{array}{l}\text { Average } \\
\text { number of } \\
\text { children } \\
\text { per woman }\end{array}$ & $\begin{array}{c}\text { Number } \\
\text { of } \\
\text { women }\end{array}$ & $\begin{array}{l}\text { Socio-economic } \\
\text { Characteristics }\end{array}$ & $\begin{array}{c}\text { Average } \\
\text { number of } \\
\text { children per } \\
\text { woman }\end{array}$ & $\begin{array}{c}\text { Number } \\
\text { of } \\
\text { women }\end{array}$ \\
\hline \multicolumn{6}{|l|}{ Woman's education } \\
\hline No formal level & 6.56 & 327 & & & \\
\hline Primary & 6.09 & 1144 & & & \\
\hline Secondary 1st cycle & 4.77 & 1893 & & & \\
\hline Secondary 2nd cycle & 3.67 & 454 & & & \\
\hline Post-secondary education & 2.77 & 110 & Critical (assets) Needs & & \\
\hline The woman's occupation & & & $\begin{array}{c}\text { Truck } \\
\text { Does not own } \\
\text { Owns }\end{array}$ & $\begin{array}{l}5.23 \\
3.69\end{array}$ & $\begin{array}{c}3801 \\
127\end{array}$ \\
\hline $\begin{array}{c}\text { Modern sector, } \\
\text { private/public administration }\end{array}$ & 3.47 & 245 & $\begin{array}{c}\text { Canoe without motor } \\
\text { Does not own } \\
\text { Owns }\end{array}$ & $\begin{array}{l}5.09 \\
6.70\end{array}$ & $\begin{array}{c}3730 \\
189\end{array}$ \\
\hline Artisan, skilled or unskilled worker & 4.23 & 85 & $\begin{array}{c}\text { Type of toilet } \\
\text { Flush }\end{array}$ & 3.89 & 210 \\
\hline Agriculture & 6.77 & 1062 & $\begin{array}{l}\text { pit/latrines } \\
\text { No toilets }\end{array}$ & $\begin{array}{l}5.07 \\
6.77\end{array}$ & $\begin{array}{c}3325 \\
393\end{array}$ \\
\hline Trade/informal sector & 4.96 & 1264 & Water Source & & \\
\hline Unemployed/inactive & 4.58 & 1272 & $\begin{array}{l}\text { Non-potable } \\
\text { Potable }\end{array}$ & $\begin{array}{l}6.18 \\
4.69\end{array}$ & $\begin{array}{l}1365 \\
2563\end{array}$ \\
\hline Economic Level & & & $\begin{array}{l}\text { Type of floor } \\
\text { Dirt floor }\end{array}$ & 6.34 & 1460 \\
\hline Not-poor & 4.17 & 1160 & Modern floor & 4.52 & 2468 \\
\hline Intermediate & 5.21 & 2059 & $\begin{array}{c}\text { Electricity } \\
\text { Does not have access }\end{array}$ & 5.66 & 2552 \\
\hline Poor & 7.00 & 709 & Has access & 4.33 & 1376 \\
\hline \multicolumn{6}{|l|}{ Critical (assets) needs } \\
\hline \multicolumn{6}{|l|}{ Radio } \\
\hline Does not own & 5.84 & 1373 & & & \\
\hline Owns & 4.84 & 2555 & & & \\
\hline Television & \multicolumn{5}{|c|}{ Vital functioning deficits } \\
\hline Does not own & 5.65 & 2725 & Durable Goods & & \\
\hline Owns & 4.16 & 1203 & Poor & 5.89 & 1091 \\
\hline Refrigerator & & & Non-poor & 4.93 & 2837 \\
\hline Does not own & 5.39 & 3407 & Sanitation & & \\
\hline Owns & 3.86 & 521 & Poor & 6.22 & 1303 \\
\hline Stove & & & Non-poor & 4.70 & 2625 \\
\hline Does not own & 5.52 & 3176 & Housing & & \\
\hline Owns & 3.76 & 752 & Poor & 6.46 & 1308 \\
\hline Moped & & & Non-poor & 4.56 & 2620 \\
\hline Does not own & 5.18 & 3841 & Region of residence & & \\
\hline Owns & 5.12 & 87 & Urban & 4.50 & 2562 \\
\hline Bicycle & & & Rural & 6.49 & 1366 \\
\hline Does not own & 5.11 & 3683 & & & \\
\hline \multirow[t]{2}{*}{ Owns } & 6.68 & 245 & & & \\
\hline & & & TOTAL & 5.19 & 3928 \\
\hline
\end{tabular}


factors. In the goal of reducing the arbitrariness in the choice of the method of data reduction, two approaches are used in recent times. The first is based on the methodology proposed by Asselin [17] and uses multiple correspondence analysis [18]. The second approach uses the confirmatory analysis with qualitative variables [19] [20]. This study is based on multiple correspondence analysis. Thus, having a wealth indicator for each household, we can subsequently classify [21] households into three groups: non-poor, intermediate and poor.

3) The Capabilities of Sen

Here, the point is to express a decomposable multidimensional poverty index, based on sub-groups and attributes $^{2}$ [22] [23]. Consider the table $X$ of the basics needs of term $x_{i j}$ measuring the quantity of the $j$-ème critical need owned by the household $i$. The multidimensional poverty index $P(X ; z)$ is expressed by:

$$
P(X ; z)=\frac{1}{n} \sum_{i=1}^{n} \sum_{j=1}^{k} \alpha_{j} g\left(\frac{x_{i j}}{z_{j}}\right)
$$

where $\alpha_{j}$ (weighting granted to critical needs) are constants $>0$ such that $\sum \alpha_{j}=1$. The gfunction, associated to $\left(x_{i j}, z_{j}\right)$ is a function of deprivation experienced by the household $i$ when the quantity of the basic need $j$ owned is inferior or equal to the level of subsistence $z_{j}$. The reproach to this multidimensional index is the arbitrary nature of the definition of poverty thresholds. It is then liable to vary according to the author's intuition.

With Sen's approach, we can consider the liberty to choose between different combinations of functioning ${ }^{3}$. As far as this study is concerned, the multidimensional analysis of poverty is limited to three dimensions of access to basic needs: durable goods, sanitation and housing. Thus, we implicitly assume [24] that the access to those needs reflects a level of well-being observed not only in relation to special understood functioning, but also in relationship with other basic needs; and those three selected needs express the capabilities to access to both private property (housing, individual sanitation environment) and to public services (sanitation, collective sanitation). Let's describe faithfully the operatory method of this approach, focusing on the three dimensions of well-being previously agreed. First of all, all categories of assets are grouped according to levels of precariousness or non-precariousness. Total precariousness is recoded 0 and the non-precariousness 1 . Secondly, within the three groups (durable goods, sanitation and housing), we tot up the precariousness mark relating to each asset. They vary respectively for durable goods, sanitation and housing from 0 to 7, 0 to 2 and 0 to 2; the maximum grade 7, 2 and 2 tally with the lack of precariousness. In these conditions, any household with a gap is declared poor; which amount to fixpovertyline $z=1$. In this context, the resulting functioning are expressed in terms of gaps or deficits compared to the level of respective subsistence $(z=1)$.

\subsubsection{Fertility Indicator}

Fertility is considered here, as a phenomenon in relation to births. In this study, the indicator used for fertility is parity: the number of children a woman gave birth during the five year preceding the survey. The drawback of this measure is known. According to Rogers (see [3]), parity refers to a past period ${ }^{4}$, while most of the measures of the standard of living are expressed in the present. Therefore, our study will not be spared by this criticism. Nevertheless, the impact of this critic can be mitigated if we consider the words of Leridon (see [3]) according to who, there will be, for a woman, a strong correlation between socio-economic status at 25 and socio-economic status at 45 .

\section{Method of Analysis}

In this study, two models have been used. The first is the linear model of classical regression: $y_{i}=x_{i} \beta+e_{i}$; $x_{i}$ is the vector of explanatory variables. It is estimated by the method of ordinary least squares. The second is the Poisson regression model [25]. It is a model adapted to the analysis of non-negative discrete variables (counting data) such as the number of children a woman gave birth to. Let $y_{i}$ be the dependent variable of counting, $y_{i}=0,1,2, \cdots$. The probability given by the Poisson distribution that $y_{i}$ is equal to a some integer $\gamma$ is:

\footnotetext{
${ }^{2}$ This index is an extension of the one-dimensional decomposition of FGT (Foster, Greer, Thorbecke) measures and at the same time an attempt to make operational the capabilities of Sen approach.

${ }^{3} \mathrm{~A}$ functioning is an achievement, whereas the capacity refers to the ability to achieve.

${ }^{4}$ The potential exists for omissions or confusion (between, for example, stillborn and live births).
} 
$\operatorname{Prob}\left(y_{i}=\gamma\right)=\frac{\mathrm{e}^{-\lambda} \lambda^{\gamma}}{\gamma !}$; the most common formulation for $\lambda_{i}$ is the log-linear model: $\ln \lambda_{i}=x_{i} \beta$. This model is estimated by the maximum likelihood method.

\section{Results}

\subsection{Descriptive Statistics}

Before giving out the results of the regression analyses, we are going to commentbriefly on descriptive statistics according to Table 1. After reading this table, we can conclude that the Congo is still in a pro-natality socio-economic context. The average number of children per woman is 5.19 children. This indicator is linked to poverty as expected. Thus, for the poor class, the average number of children for a woman is 7 , intermediate class 5, and non-poor class 4.17 children. In other words, if we refer to critical assets, we will find out that the average number of children per woman for a poor class is 5.89 compared to 4.93 for non-poor when we consider durable goods; 6.22 for poor class and 4.70 for non-poor for sanitation and 6.46 for poor compared to 4.56 for non-poor for housing. The number of children per woman depends on her education level in a decreasing way; an uneducated woman has an average of 6.56 children, a woman who attends university has an average of 2.77, decreasing from 6.09 for a woman with a primary education level to 4.77 with a middle school education level to 3.67 with high school education level. Finally, we can state that the rural environment differs from urban environment because of a higher average of fertility; 6.49 children per woman compare to 4.56 in cities, a difference of almost two children.

\subsection{Critical Assets Approach}

Table 2 shows the results of the econometric estimations of the two models with the various assets held by households as explanatory variables. When it comes to the technic of estimation, we must specify that we observed five significant variables in the case of ordinary least squares compared to two only in Poisson model.

Table 2. Regression coefficients and marginal effects of estimates of the relationship between the critical needs (assets) and fertility.

\begin{tabular}{|c|c|c|c|c|c|}
\hline \multirow{2}{*}{ Critical Assets } & \multicolumn{2}{|c|}{ OLS } & \multicolumn{3}{|c|}{ Poisson } \\
\hline & Coef & T-stat & Coef & T-stat & ef.mg \\
\hline Radio & -0.0390253 & -1.36 & -0.0403799 & -1.09 & -0.0356587 \\
\hline Television & -0.0226455 & -0.56 & -0.0292492 & -0.52 & -0.025527 \\
\hline Refrigerator & -0.0653492 & -1.37 & -0.0965544 & -1.37 & -0.0818217 \\
\hline Stove & -0.0899139 & $-2.24^{* *}$ & -0.1218664 & $-2.08^{* *}$ & $-0.1030753^{* *}$ \\
\hline Moped & 0.0939173 & $1.74^{*}$ & 0.0901356 & 1.38 & 0.0823203 \\
\hline Truck & -0.0608953 & -0.80 & -0.0866054 & -0.74 & -0.0730168 \\
\hline Canoe without motor & 0.0428819 & 0.71 & 0.0393904 & 0.54 & 0.0351919 \\
\hline Type of toilet (modern) & 0.0631273 & 1.02 & 0.828013 & 0.93 & 0.0754313 \\
\hline Potable or non potable drinking water & -0.061586 & $-1.88^{*}$ & -0.063624 & -1.52 & -0.056395 \\
\hline Type of floor & -0.1669586 & $-4.91^{* * *}$ & -0.1747426 & $-3.99^{* * *}$ & $-0.1570439^{* * *}$ \\
\hline Access to electricity & -0.650666 & $-1.79^{*}$ & -0.076834 & -1.54 & -0.0666803 \\
\hline Constant & 1.109985 & 38.50 & 0.1098673 & 3.11 & \\
\hline$N=3928$ & & & & \multicolumn{2}{|c|}{$\mathrm{N}=3928$} \\
\hline$F(11,3916)=15.34$ & & & & \multicolumn{2}{|c|}{ LR CHI $(11)=121.87$} \\
\hline $\mathrm{R}^{2}=0.0413$ & & & & \multicolumn{2}{|c|}{ Log Likelihood $=-4580.73$} \\
\hline
\end{tabular}

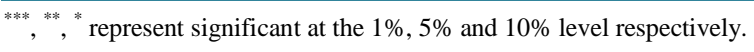


Therefore, there are homogeneity of the results for two variables only: the possession of a stove and the type of floor. If we consider the ordinary least squares, four out of five variables have negative effect on fertility: that is the case for possession of a stove, access to a proper floor, safe drinking water and electricity. Indeed, the possession of a stove by the household reduces fertility by 0.0899 children. Moreover, the inequalities to access to drinking water, electricity, and a type of floor lead respectively to a fertility reduce of $0.0615,0.651$ and 0.1669 children. In the other hand, the Poisson model indicates that the possession of an additional stove by the household reduces 0.10 points to fertility; while access to a modern floor reduces 0.157 points.

\subsection{Socio-Economic Stratification of the Standard of Living}

Note that we have completed a multiple correspondence analysis of the table crossing households and basic needs. The first factor counts for $28 \%$ of the total inertia of the table and the plot (1.2) accumulates almost $39 \%$ of this same inertia. Then an ascending hierarchical classification into three classes has been used: $30.8 \%$ non-poor, $53.9 \%$ intermediate and $15.3 \%$ poor. In fact, the last two classes represent the poor and extremely poor, which amount $69.3 \%$ of poor. When related to the econometric results, they are very significant (at the threshold of 1\%) for intermediate class and for poor class, and are homogeneous for both technical estimations. Thus, the two analyzed factors have a positive impact on children supporting demand, the theory sustaining that poverty is the origin of a high fertility rate. Obviously, if we consider the results provided by the OLS method (Table 3), we notice that the fact that a woman belongs to the intermediate class rather than the non-poor class increases fertility to 0.175 children, all things being equal. Likewise, the belonging of a woman to the poor household goes along with an increase of the number of children to 0.466 . The same interpretation can also be made in Poisson model: the belonging of a woman to intermediate and poor household leads to an increase in fertility, of respectively 0.19 and 0.52 children.

\subsection{Critical Functionings}

We can notice that, the results obtained in Table 4, are to a certain extent in harmony with those provided for critical assets. Apart from the coefficient of durable goods which is only significant (at the threshold of $10 \%$ ) in the case of OLS, the coefficients of the two other functioning are very significant (at the threshold of $1 \%$ ) regardless of the econometric option used (Table 4).

We also notice that all of these functioning have a negative impact on the number of children. The possession of durable goods by the household reduces parity of 0.053 children. In one hand, differences in terms of access to a sanitary living environment and to decent housing reduces fertility respectively to 0.102 and 0.236 children if we refer to the OLS estimation. In the other hand, in Poisson model, the inequalities relating to access to a sanitary living environment and to adequate housing reduce respectively in the parity 0.10 and 0.232 children.

\subsection{The Determinants of Fertility and Non-Monetary Poverty}

The modelling as presented appears to be attractive for the study of poverty-fertility relationship, however it

Table 3. Regression coefficients and marginal effects of estimates of the relationship between socio-economic stratification and fertility.

\begin{tabular}{cccccc}
\hline \multirow{2}{*}{ Socio-economic stratification } & \multicolumn{2}{c}{ OLS } & & \multicolumn{2}{c}{ Poisson } \\
\cline { 2 - 6 } & Coef & T-stat & Coef & T-stat & ef.mg \\
\hline Intermediate & 0.175425 & $5.97^{* * *}$ & 0.2188004 & $5.24^{* * *}$ & $0.1920176^{* * *}$ \\
Poor & 0.4661155 & $12.21^{* * *}$ & 0.5006981 & $10.23^{* * *}$ & $0.5227616^{* * *}$ \\
Constant & 0.7172414 & 30.51 & -0.3323428 & -9.50 & $\mathrm{~N}=3928$ \\
$\mathrm{~N}=3928$ & & & & LR CHI (2) $=103.73$ \\
$\mathrm{~F}(2,3925)=74.55$ & & & & Log Likelihood $=-4589.79$ \\
$\mathrm{R}^{2}=0.0366$ & & & & &
\end{tabular}

${ }_{* * *}^{* *}, \stackrel{*}{ }$ represent significant at the $1 \%, 5 \%$ and $10 \%$ level respectively. 
Table 4. Regression coefficients and marginal effects of estimates of the relationship between critical functionings and fertility.

\begin{tabular}{cccccc}
\hline \multirow{2}{*}{ Critical functionings } & \multicolumn{3}{c}{ OLS } & \multicolumn{3}{c}{ Poisson } \\
\cline { 2 - 6 } & Coef & T-stat & Coef & T-stat & ef.mg \\
\hline Durable goods & -0.0530778 & $-1.78^{*}$ & -0.0567601 & -1.49 & -0.0506653 \\
Sanitation & -0.1025828 & $-3.18^{* * *}$ & -0.109661 & $-2.64^{* * *}$ & $-0.0984997^{* * *}$ \\
Housing & -0.2362979 & $-7.18^{* * *}$ & -0.2517786 & $-5.99^{* * *}$ & $-0.2320369^{* * *}$ \\
Constant & 1.157832 & 40.06 & 0.1558781 & 4.47 & N $=3928$ \\
$\mathrm{~N}=3928$ & & & & LR CHI (3) $=97.87$ \\
$\mathrm{~F}(3,3924)=46.91$ & & & & Log Likelihood $=-4592.72$ \\
$\mathrm{R}^{2}=0.0346$ & & & &
\end{tabular}

may seem too simplistic [5]. Therefore, the model must be improved to take into account special features of developing countries, in which children are considered as a relevant labor source, and an insurance against the vagaries of the economic situation or the risks of age in the other hand. The model should be extended to the limit of taking into account demographic, cultural and medical aspects ${ }^{5}$ [26]. The poverty-fertility relationship is then enriched with additional variables called control variables. The effect of non-monetary poverty on fertility is the assessment by controlling variables such as woman's education, professional activity, marital status or the presence of a husband/partner in the household or even the place of the region of residence.

Tables 5-7 show that the introduction of these variables change a little the results obtained in direct relationship. Considering the relationship between critical assets and fertility (Table 5), only one asset has a significant coefficient. It is the possession of a stove. The impact of this asset on fertility remains negative and it coefficient still stable in absolute value: 0.0878 compared to 0.0899 in direct relationship and 0.091187 and 0.10307 respectively for the marginal effects. In the socio-economic stratification of household standard of living approach (Table 6), results obtained with this approach are similar to those in the direct relationship. The classes (middle and poor) hold the same level of significance in the two econometric procedures and the sign of their impact remains the same: poverty is the origin of a high fertility. However, in case of the linear model, there is a decrease in the value of coefficients and an increase of marginal effect in Poisson model. Thus, the belonging of a woman to the middle class increases 0.101 children to fertility compared to 0.175 in the direct relationship. For the poor class we have 0.227 children increase after introducing the control variables compared to 0.466 in the direct relationship. In Poisson specification, the marginal effect associated with a woman belonging to the middle class increase 0.1026 to children number compared to 0.1920 in direct relationship. For poor households, this effect was 0.5227 in direct relationship compared to 0.2073 after introduction of control variables.

Finally, with Sen's approach of capabilities (Table 7), the coefficients of the three functioning have the same signs like those observed in the direct relationship; however housing is the single coefficient that maintains a significant influence in both econometric procedures. This coefficient in both cases has decreased in absolute value.

Now, we are going to consider the impact of the introduction of control variables. Those variables are demographic ones. The first is the woman's education, expressed here by the level of education. There are relevant documents about education-fertility relationship. The impact of education on fertility decline is well-known.

Considering this, we are sure that education [27]:

- delays the marriage age and then reduces the duration of reproductive life;

- limit the number of desired children;

- remove barriers to contraception, especially by reducing the psychological cost;

- strengthens women's autonomy;

- Increases women's autonomy relating to their own body and their ability to refuse unwanted sex.

Three out of four modalities of this variable are significant. Middle, high school and university levels have a

\footnotetext{
${ }^{5}$ The epidemiological aspect allows you to highlight the process that could lead to the death of a child and to deduce the potential instruments to identify the impact of child mortality on fertility. The cultural aspect can guide the choice of assumptions and of the exogenous variables.
} 
Table 5. Estimate of the relationship between critical needs, fertility and control variables.

\begin{tabular}{|c|c|c|c|c|c|}
\hline & \multicolumn{2}{|c|}{ OLS } & \multicolumn{3}{|c|}{ Poisson } \\
\hline & Coef & T-stat & Coef & T-stat & ef.mg \\
\hline \multicolumn{6}{|l|}{ Critical Assets } \\
\hline Radio & -0.0435081 & -1.60 & -0.436815 & -1.16 & -0.0356851 \\
\hline Television & -0.0308478 & -0.81 & -0.0403701 & -0.71 & -0.0325082 \\
\hline Refrigerator & 0.0003568 & 0.01 & -0.0199193 & -0.28 & -0.0160474 \\
\hline Stove & -0.087865 & $-2.27^{* *}$ & -0.11732 & $-1.95^{* *}$ & $-0.0918756^{* *}$ \\
\hline Moped & 0.0416895 & 0.79 & 0.0404609 & 0.59 & 0.0334237 \\
\hline Truck & -0.0769589 & -1.07 & -0.1073289 & -0.92 & -0.0828755 \\
\hline Canoe without motor & 0.0357257 & 0.61 & 0.0366834 & 0.48 & 0.0302661 \\
\hline Type of toilet (modern) & 0.0883512 & 1.51 & 0.117207 & 1.92 & 0.1002841 \\
\hline Potable or non potable drinking water & 0.0094436 & 0.26 & 0.005465 & 0.11 & 0.0044313 \\
\hline Type of floor & -0.0429599 & -1.18 & -0.0399643 & -0.79 & -0.0326008 \\
\hline Access to electricity & -0.0508613 & -1.46 & -0.0560019 & -1.09 & -0.0450733 \\
\hline \multicolumn{6}{|l|}{ Woman's education } \\
\hline Primary & 0.242909 & 0.50 & $8.74 \mathrm{e}^{-}-06$ & 0.00 & $7.09 \mathrm{e}-06$ \\
\hline Secondary 1st cycle & -0113648 & -2.34 & -0.1405137 & $-2.11^{* *}$ & $-0.1138343^{* *}$ \\
\hline Secondary 2nd cycle & -0.1437307 & $-2.38^{* *}$ & -0.18524 & $-2.11^{* *}$ & -0.1401941 \\
\hline Post secondary & -0.2108772 & $-2.32^{* *}$ & -0.1699521 & $-1.87^{* *}$ & $-0.19345^{* *}$ \\
\hline \multicolumn{6}{|l|}{ Woman's age } \\
\hline 25 - 29 years & 0.179858 & $5.10^{* * *}$ & 0.1840607 & $3.94^{* * *}$ & $0.1575811^{* * *}$ \\
\hline $30-34$ years & 0.1235103 & $3.31^{* * *}$ & 0.1307454 & $2.62^{* * *}$ & $0.1106378^{* *}$ \\
\hline 35 - 39 years & -0.0408056 & -1.03 & -0.0376792 & -0.68 & -0.0301853 \\
\hline $40-44$ years & -0.3546624 & $-7.71^{* * *}$ & -0.4694844 & $-6.23^{* * *}$ & $-0.3194049^{* * *}$ \\
\hline $45-49$ years & -0.77855 & $-14.18^{* * *}$ & -1.509332 & $-11.09^{* * * *}$ & -0.7028519 \\
\hline \multicolumn{6}{|l|}{ The woman's occupation } \\
\hline Artisan, skilled worker or not & -0.19558216 & $-2.01^{* *}$ & -0.1608643 & -0.99 & -0.1210065 \\
\hline Agriculture & 0.1810804 & $2.78^{* * *}$ & 0.265516 & $2.47^{* *}$ & $0.2296918^{* *}$ \\
\hline Trade/informal sector & 0.0126687 & 0.22 & 0.1070923 & 1.08 & 0.886246 \\
\hline Unemployed/inactive & -0.0129157 & -0.23 & 0.0816673 & 0.83 & 0.0672539 \\
\hline \multicolumn{6}{|l|}{ Marital Status } \\
\hline Married & 0.0478297 & $1.74^{*}$ & 0.0487817 & 1.27 & 0.0399128 \\
\hline \multicolumn{6}{|l|}{ Presence of the partner/husband } \\
\hline Lives with her & 0.2036176 & $5.83^{* * *}$ & 0.2463288 & $4.54^{* * *}$ & $0.1837007^{* * *}$ \\
\hline \multicolumn{6}{|l|}{$\begin{array}{l}\text { Discussion with the partner on the use of } \\
\text { family planning }\end{array}$} \\
\hline One or two times & 0.1346045 & $4.72^{* * *}$ & 0.1454871 & $3.66^{* * *}$ & $0.1220626^{* * *}$ \\
\hline Often & 0.1765198 & $5.56^{* * *}$ & 0.1981152 & $4.47^{* * *}$ & $0.17056^{* * *}$ \\
\hline \multicolumn{6}{|l|}{ Place of residence } \\
\hline Urban & -0.0601594 & -1.32 & -0.552214 & -0.87 & -0.0451974 \\
\hline \multicolumn{6}{|l|}{ Region of Residence } \\
\hline South & -0.0212971 & -0.67 & -0.008606 & -0.18 & -0.0069841 \\
\hline North & 0.0265308 & 0.61 & 0.0382854 & 0.61 & 0.0314087 \\
\hline Constant & 0.821824 & 8.91 & -0.3209548 & -2.25 & \\
\hline $\mathrm{N}=3928$ & & \multicolumn{4}{|c|}{$\mathrm{N}=3928$} \\
\hline$F(31,3896)=24.68$ & & \multicolumn{4}{|c|}{ LR CHI (31) = 545.24} \\
\hline $\mathrm{R}^{2}=0.164$ & & \multicolumn{4}{|c|}{ Log Likelihood $=-4369.04$} \\
\hline
\end{tabular}

${ }^{* * *},{ }^{* *},{ }^{*}$ represent significant at the $1 \%, 5 \%$ and $10 \%$ level respectively. 
Table 6. Estimate of the relationship between the socio-economic stratification, fertility and control variables.

\begin{tabular}{|c|c|c|c|c|c|}
\hline & \multicolumn{2}{|c|}{ OLS } & \multicolumn{3}{|c|}{ Poisson } \\
\hline & Coef & T-stat & Coef & T-stat & ef.mg \\
\hline \multicolumn{6}{|l|}{ Socio-economic stratification } \\
\hline Intermediate & 0.1011634 & $3.29^{* * *}$ & 0.126532 & $2.71^{* * *}$ & $0.102604^{* * *}$ \\
\hline Poor & 0.2275723 & $4.38^{* * *}$ & 0.2359649 & $3.30^{* * *}$ & $0.2073002^{* * *}$ \\
\hline \multicolumn{6}{|l|}{ Woman's education } \\
\hline Primary & 0.0274842 & 0.57 & 0.0021942 & 0.06 & 0.0017843 \\
\hline Secondary 1st cycle & -0.1113195 & $-2.30^{* *}$ & -0.1399552 & $-2.11^{* *}$ & $-0.113566^{* *}$ \\
\hline Secondary 2nd cycle & -0.1489061 & $-2.48^{* *}$ & -0.197864 & $-2.26^{* *}$ & $-0.1492948^{* *}$ \\
\hline Post secondary & -0.2218781 & $-2.47^{* *}$ & -0.2877696 & $-2.01^{* *}$ & -0.2049072 \\
\hline \multicolumn{6}{|l|}{ Woman's age } \\
\hline 25 - 29 years & 0.1722193 & $4.89^{* * *}$ & 0.1745833 & $3.74^{* * *}$ & $0.149287^{* * *}$ \\
\hline 30 - 34 years & 0.1184225 & $3.19^{* * *}$ & 1232247 & $2.48^{* *}$ & 0.1041874 \\
\hline 35 - 39 years & -0.0456813 & -1.15 & -0.0437455 & -0.79 & -0.0350294 \\
\hline 40 - 44 years & -0.3555101 & $-7.75^{* * *}$ & -0.473547 & $-6.29^{* * *}$ & $-0.3222244^{* * *}$ \\
\hline 45 - 49 years & -0.7811679 & $-14.25^{* * * *}$ & -1.514956 & $-11.14^{* * *}$ & $-0.7053895^{* * *}$ \\
\hline \multicolumn{6}{|l|}{ The woman's occupation } \\
\hline Artisan, skilled worker or not & -0.1816505 & $-1.87^{* * *}$ & -0.1438164 & -0.88 & -0.1092215 \\
\hline Agriculture & 0.198303 & $3.09^{* * *}$ & 0.2886649 & $2.71^{* * *}$ & $0.2515894^{* *}$ \\
\hline Trade/informal sector & 0.0251807 & 0.44 & 0.1215785 & 1.23 & 0.1010501 \\
\hline Unemployed/inactive & -0.0009811 & -0.02 & 0.0949366 & 0.97 & 0.0784989 \\
\hline \multicolumn{6}{|l|}{ Marital Status } \\
\hline Married & 0.0433358 & 1.58 & 0.0454407 & 1.18 & 0.0372183 \\
\hline \multicolumn{6}{|l|}{ Presence of the partner/husband } \\
\hline Lives with her & 0.1954797 & $5.62^{* * *}$ & 0.2370905 & $4.39^{* * *}$ & $0.1776436^{* * *}$ \\
\hline \multicolumn{6}{|c|}{$\begin{array}{l}\text { Discussion with the partner on the use } \\
\text { of family planning }\end{array}$} \\
\hline One or two times & 0.1371535 & $4.81^{* * *}$ & 0.1480747 & $3.74^{* * *}$ & $0.1245105^{* * *}$ \\
\hline Often & 0.1780006 & $5.61^{* * *}$ & 0.1986584 & $4.49^{* * *}$ & $0.1713333^{* * *}$ \\
\hline \multicolumn{6}{|l|}{ Place of residence } \\
\hline Urban & -0.0515603 & -1.30 & -0.0526361 & -0.95 & -0.0431338 \\
\hline \multicolumn{6}{|l|}{ Region of Residence } \\
\hline South & -0.0197155 & -0.63 & -0.0103249 & -0.22 & -0.0083927 \\
\hline North & 0.0035532 & 0.08 & 0.0148052 & 0.4 & 0.0120847 \\
\hline Constant & 0.6368527 & 6.81 & -0.5249819 & -3.64 & \\
\hline $\mathrm{N}=3928$ & \multicolumn{5}{|c|}{$\mathrm{N}=3928$} \\
\hline $\mathrm{F}(22,3905)=34.34$ & \multicolumn{5}{|c|}{ LR CHI (22) = 536.65} \\
\hline $\mathrm{R}^{2}=0.1621$ & \multicolumn{5}{|c|}{ Log Likelihood = -4373.33 } \\
\hline
\end{tabular}

***, ${ }^{* *},{ }^{*}$ represent significant at the $1 \%, 5 \%$ and $10 \%$ level respectively. 
Table 7. Estimate of the relationship between the critical functionalities, fertility and controle variables.

\begin{tabular}{|c|c|c|c|c|c|}
\hline & \multicolumn{2}{|c|}{ OLS } & \multicolumn{3}{|c|}{ Poisson } \\
\hline & Coef & T-stat & Coef & T-stat & ef.mg \\
\hline \multicolumn{6}{|l|}{ Critical functionings } \\
\hline Durable goods & -0.0423038 & -1.48 & -0.0451304 & -1.16 & -0.0370841 \\
\hline Sanitation & -0.0037409 & -0.10 & -0.0095425 & -0.19 & -0.0077748 \\
\hline Housing & -0.0969402 & $-2.73^{* * *}$ & -0.0978292 & $-2.00^{* *}$ & $-0.0809213^{* *}$ \\
\hline \multicolumn{6}{|l|}{ Woman's education } \\
\hline Primary & 0.027259 & 0.57 & 0.0036439 & 0.06 & 0.0029664 \\
\hline Secondary 1st cycle & -0.1190105 & $-2.46^{* *}$ & -0.1464629 & $-2.21^{* *}$ & $-0.11893^{* *}$ \\
\hline Secondary 2nd cycle & -0.1679079 & $-2.80^{* * * *}$ & -0.2190369 & $-2.52^{* *}$ & $-0.1641127^{* * *}$ \\
\hline Post secondary & -0.2415547 & $-2.69^{* * *}$ & -0.3120747 & $-2.19^{* * *}$ & $-0.2199754^{* *}$ \\
\hline \multicolumn{6}{|l|}{ Woman's age } \\
\hline 25 - 29 years & 0.1709642 & $4.85^{* * *}$ & 0.1737307 & $3.72^{* * * *}$ & $0.1486304^{* * *}$ \\
\hline 30 - 34 years & 0.1146359 & $3.08^{* * * *}$ & 0.1200152 & $2.41^{* *}$ & $0.1014433^{* * *}$ \\
\hline 35 - 39 years & -0.0449188 & -1.13 & -0.0428858 & -0.77 & -0.0343765 \\
\hline 40 - 44 years & -0.3605652 & $-7.86^{* * *}$ & -0.4779527 & $-6.35^{* * *}$ & $-0.3249541^{* * *}$ \\
\hline 45 - 49 years & -0.7764422 & $-14.14^{* * *}$ & -1.507331 & $-11.07^{* * *}$ & $-0.7040135^{* * *}$ \\
\hline \multicolumn{6}{|l|}{ The woman's occupation } \\
\hline Artisan, skilled worker or not & -0.1618366 & $-1.67^{*}$ & -0.1156498 & -0.71 & -0.0890607 \\
\hline Agriculture & 0.2125481 & $3.30^{* * *}$ & 0.3093498 & $2.91^{* * *}$ & $0.2712418^{* * *}$ \\
\hline Trade/informal sector & 0.0424021 & 0.75 & 0.146781 & 1.50 & 0.1226719 \\
\hline Unemployed/inactive & 0.0102055 & 0.18 & 0.112982 & 1.15 & 0.0938015 \\
\hline \multicolumn{6}{|l|}{ Marital Status } \\
\hline Married & 0.0420941 & 1.54 & 0.0437062 & 1.14 & 0.0358137 \\
\hline \multicolumn{6}{|l|}{ Presence of the partner/husband } \\
\hline Lives with her & 0.199034 & $5.70^{* * *}$ & 0.2404687 & $4.44^{* * *}$ & $0.1801055^{* * *}$ \\
\hline \multicolumn{6}{|c|}{$\begin{array}{l}\text { Discussion with the partner on the use of } \\
\text { family planning }\end{array}$} \\
\hline One or two times & 0.1324458 & $4.65^{* * *}$ & 0.1432071 & $3.62^{* * *}$ & $0.1203692^{* * *}$ \\
\hline Often & 0.1725712 & $5.44^{* * *}$ & 0.1932737 & $4.37^{* * *}$ & $0.166538^{* * *}$ \\
\hline \multicolumn{6}{|l|}{ Place of residence } \\
\hline Urban & -0.0644515 & -1.47 & -0.0606574 & -0.99 & -0.0498065 \\
\hline \multicolumn{6}{|l|}{ Region of Residence } \\
\hline South & -0.0258505 & -0.83 & -0.0142822 & -0.31 & -0.0116181 \\
\hline North & 0.0327191 & 0.77 & 0.0464635 & 0.77 & 0.0382973 \\
\hline Constant & 0.8277578 & 9.01 & -0.324343 & -2.29 & \\
\hline $\mathrm{N}=3928$ & \multicolumn{5}{|c|}{$\mathrm{N}=3928$} \\
\hline $\mathrm{F}(23,3904)=32.39$ & \multicolumn{5}{|c|}{ LR CHI (23) = 531.47} \\
\hline $\mathrm{R}^{2}=0.16$ & \multicolumn{5}{|c|}{ Log Likelihood $=-4375.92$} \\
\hline
\end{tabular}

***, ${ }^{* *},{ }^{*}$ represent significant at the $1 \%, 5 \%$ and $10 \%$ level respectively. 
negative impact on fertility. For instance the marginal effect related to an additional year in high school is -0.14 regarding critical assets, -0.15 for socio-economic stratification and -0.16 for critical functioning.

The second explanatory variable studied is age groups. Age is considered as an indicator of the physical health and the reproductive capacity of a woman. According to the significance and the sign of the coefficients, results are the same regardless of the econometric option and poverty index. The younger age groups, 25 - 29 and 30 - 34 have a positive effect on fertility compared to a negative impact of older age groups (40 - 44 and 45 49). This can be explained by the definition of the dependent variable and by teen fertility in Congo.

The third control variable is the occupation of the woman. Along with education, this variable is an important key of fertility. The estimated model enables to conclude that the traditional craft sector, qualified workers and the agricultural sector have a significant influence on fertility. The fact that a woman works in the agricultural sector rather than in the modern sector (private/public administration) increases fertility, all things being equal; the latter decreases (only in the OLS) in case when the woman works in the traditional crafts sector or belongs to the category of qualified workers or not.

The marital status of the woman is the fourth control variable introduced in the model. As a fertility factor, this variable has the expected sign, meaning that it has a positive impact on fertility. Nevertheless, it is not significant.

The presence of partner/husband in the household was selected as a variable reflecting to the household composition. This variable affects positively fertility.

The sixth control variable studied concerns the use of family planning. This variable express the social cost of birth control and thus it is an important determinant on fertility then. The two estimation technics OLS and Poisson show that the sign of the relationship between parity and this variable is the same regardless of the parity indicator. The use of family planning is strongly related to fertility.

Considering the living area of households, the results show that the regression coefficients of the place and region of residence have the expected sign in accordance with the descriptive statistics (Table 1); however they are not significant. We can conclude that both of these variables do not affect child demand.

\section{Discussion}

Does poor have a high fertility? The idea that has become almost axiomatic among many researchers (see [2]) is, to some extent, confirmed in our study; first in view of descriptive statistics, then in the light of regression analyses. Indeed, it is obvious, when considering critical assets (durable goods, sanitation and housing), that poor have more children than others. This is also verified in the case of the economic stratification of the household standard of living: a higher number of children is found in poor class. The latter result is also confirmed in matter of regression analyses. The poor class has a positive and very significant influence on fertility. When it comes to the functioning, the relationship between them and fertility is definitely proved for two functioning, sanitation and housing; however it is somewhat less so for durable goods.

In this study, we also notice that other factors could differentiate poor from others. For instance, education level which is a key variable in the study of fertility. The World Bank lays emphasis in a report that "the poor people with a poor education level ... have highest fertility" (see [2]). This assertion is not denied in this document. The results show that, the lower the level of education, the higher the fertility. As pointed out in [28], educated women are the first to break with traditional model of fertility which connects their status to the number of their progeny (to enter later into union and to use modern methods of contraception).

We assume that the woman's age influence fertility during the five years preceding the survey [5]. This assumption is only verified for the age groups between 20 - 25 and 30 - 34. A negative effect is observed compare to the upper age groups $40-44$ and 45 - 49 . These results are somehow paradoxical compare to previous works.

The women's professional activity is a factor linked with both education and income. When a woman works, freedom and flexibility gives her greater autonomy in controlling of her progeny [5]. We notice that only one modality of this variable has a positive impact on child demand regardless of poverty index or model used; obviously it is the agricultural sector.

The study also shed light over the fact the marital status of a woman is not a determinant on child demand, compare to other empirical studies.

We assume that the presence of a partner/husband in the household increase fertility, which is verified in our sample. Indeed, the presence of a partner/husband in the household appears to have a constant influence on the 
number of children already born.

Discussions between partners on reproductive health issues play an important role on fertility. Considered as a psychosocial variable representing the social cost of family planning [29], discussing the use of family planning with the spouse is likely to have an impact on fertility, which is shown in our study.

Finally, many studies have highlighted the regional and residential dimension of fertility. This is confirmed in descriptive statistics. However in the case of regression analysis, these two dimensions do not impact the child demand.

\section{Conclusions}

The purpose of study was to explore the relationship between non-monetary poverty and fertility, using data from Congo 2005 Demographic and Health Survey. To do this we started by analyzing the direct relationship between poverty and fertility. We have used three types of poverty indicators to achieve this goal: critical assets, socio-economic stratification of household standard of living and Sen's functioning. The study has shown that in one hand, the choice of poverty index had a considerable influence on the intensity of this relationship; and if one refers to the widespread idea, originating from the "New Home Economics", according to which poverty is the origin of high fertility, this assertion is corroborated (in case of economic stratification of the standard of living) or rejected (in case of functioning or certain assets) according to the poverty indices selected in the other hand. Subsequently, the analysis has been strengthened with the introduction of other explanatory variables that took into account economic, demographic, cultural or social aspects. This allowed us to see the right impact of non-monetary poverty on fertility. The introduction of these variables changes few results in the direct relationship between poverty and fertility.

Nevertheless, this study has some limitations that we must mention. Notably, in the relationship between poverty and fertility, the health survey did not give us much choice in the selection of indicators of fertility and poverty. Accordingly, we have abandoned the monetary measures of poverty in favor of non-income measures. In addition, there is a difference between successful fertility rates, which refers to a past period, compared with the poverty rate that refers to the current period. This time lag can generally limit the scope of the results. Another interesting improvement in a future study of the relationship between fertility and poverty could be to explore several indicators of fertility and poverty if data are available.

\section{References}

[1] Schoumaker, B. (2004) Pauvreté et fécondité en Afrique Sub-saharienne: une analyse comparative des enquêtes démographiques et de santé. African Population Studies, Supplement A, 19, 13-44.

[2] Schoumaker, B. (1998) Pauvreté et fécondité: Un aperçu de la littérature des 25 dernières années. In: Gendreau, F., Ed., Crises, Pauvreté et Changements Démographiques dans les Pays du Sud, Editions Estem, 99-116.

[3] Schoumaker, B. and Tabutin, D. (1999) Relations entre pauvreté et fécondité dans les pays du sud. Etat de connaissances, méthodologie et illustrations. Document de Travail No. 2, Université catholique De Louvain.

[4] Lachaud, J.-P. (1998) La pauvreté en Mauritanie: Une approche multidimensionnelle. Centre d’Economie de Développement, Document de travail No. 36, Université Montesquieu, Bordeaux IV.

[5] Beaulière, A. (2004) Pauvreté et fécondité en Haïti, Centre d’Economie de Développement, Document de travail No. 141, Université Montesquieu, Bordeaux IV.

[6] Sen, A. (1985) Commodities and Capabilities. Amsterdam, North-Holland.

[7] Kuklys, W. (2005) Amartya Sen’s Capabiliy Approach. Theoretical Insights and Empirical Applications, Springer.

[8] CNSEE and ORC Macro (2005) Enquête Démographique et de Santé du Congo, Calverton, Maryland.

[9] Ravallion, M. (1996) Comparaisons de pauvreté. Concepts et méthodes, Document de travail LSMS No. 122, Banque Mondiale, Washington DC.

[10] Foster, J.E. Greer, J. and Thorbecke, E. (1984) A Class of Decomposable Poverty Measures. Econometrica, 52, 761766. http://dx.doi.org/10.2307/1913475

[11] Bollen, K.A. Glanville, J.L. and Stecklov, G. (2002) Economic Status and Proxies in Studies of Fertility in Developing Countries: Does Measures Matter? Population Studies, 56, 81-96. http://dx.doi.org/10.1080/00324720213796

[12] Filmer, D. and Pritchett, L. (2001). Estimating Wealth Effects with Expenditure Data or Tears: An Application to Educational Enroments in States of India. Demography, 38, 115-132. 
[13] Montgomery, M.R., Gragnolati, M., Burke, K. and Paredes, E. (2000) Measure Living Standards with Proxy Variables. Demography, 37, 155-174. http://dx.doi.org/10.2307/2648118

[14] Sahn, D.E. and Stifel, D.C. (2000) Poverty Comparisons over Time and across Countries in Africa. World Development, 28, 2123-2155. http://dx.doi.org/10.1016/S0305-750X(00)00075-9

[15] Lebart, L., Morineau, A. and Piron, M. (1995) Statistique Exploratoire Multidimensionnelle. Dunod, Paris.

[16] Meulman, J.J. (1992) The Integration of Multidimensional Scaling and Multivariate with Optimal Transformation. Psychometrica, 57, 539-565. http://dx.doi.org/10.1007/bf02294419

[17] Asselin, L.-M. (2009) Analysis of Multidimensional Poverty. Theory and Case Studies, Springer. http://dx.doi.org/10.1007/978-1-4419-0843-8

[18] Greenacre, M. and Blasius, J. (2006) Multiple Correspondence Analysis and Related Methods. Chapman \& Hall/CRC. http://dx.doi.org/10.1201/9781420011319

[19] Moustaki, I. (2000) Latent Variable Model for Ordinal Variables. Applied Psychological Measurement, 24, $211-223$. http://dx.doi.org/10.1177/01466210022031679

[20] Jöreskog, K.G. and Moustaki, I. (2001) Factor Analysis of Ordinal Variables: A Comparison of Three Approaches. Multivariate Behavioral Research, 36, 347-387. http://dx.doi.org/10.1207/S15327906347-387

[21] Anderson, T.W. (1958) An Introduction to Multivariate Statistical Analysis. John Wiley \& Sons, New York.

[22] Chakravarty, S.R., Mukherjee, D. and Ranade, R.R. (1997) On the Family of Subgroups and Factors Decomposable Measures of Multidimensional Poverty. In: Slottje, D.J., Ed., Research on Economic Inequality, 8, JAI Press INC, London, 175-194.

[23] Bourguignon, F. and Chakravarty, S.R. (2003) The Measurement of Multidimensional Poverty. Journal of Economic Inequality, 1, 25-49. http://dx.doi.org/10.1023/A:1023913831342

[24] Lachaud, J.P. (1999) Le differentiel spatial de pauvreté au Burkina Faso. Capabilities versus dépenses, Centre d’Economie de Développement, Document de travail No. 36, Université Montesquieu, Bordeaux IV.

[25] Cameron, A.C. and Trivedi, P.K. (1998) Regression Analysis of Count Data. Cambridge University Press. http://dx.doi.org/10.1017/CBO9780511814365

[26] Picard-Tortorici, N. (1999) Démographie et économie de la famille dans les pays en développement. Economie Publique, 3-4, 189-223.

[27] Joshi, H. and David, P. (2002) Le contexte économique et social de la fécondité, In Démographie: Analyse et synthèse, II Les Déterminants de la Fécondité, Editions de l’Institut National d’Etudes Démographiques, Paris, 327-374.

[28] Mboup, G. (2000) Transition de la fécondité et pratique contraceptive en Afrique anglophone, In Politiques démographiques et Transition de la Fécondité en Afrique, L’Harmattan, Paris, 133-170.

[29] Anoh, A. (2001) La progression inégale de la planification familiale à Aboisso (Côte d'Ivoire), Communication au 2ème atelier de l'unité de Recherche (UR) “santé de la reproduction, fécondité et développement”. Institut de Recherche et de Développement (IRD), Paris. 